\title{
Dolegliwości bólowe odcinka lędźwiowo-krzyżowego wynikające z zaburzenia lordozy lędźwiowej
}

\section{Lumbosacral ailments resulting from deviation of the lumbar lordosis}

\author{
Wioletta Jagucka-Mętel', Anna Machoy-Mokrzyńska', Adam Nowicki², Adam Figeland³ ${ }^{3}$ Ewa Sobolewska4凶 \\ 1 Pomorski Uniwersytet Medyczny w Szczecinie, Katedra i Zakład Farmakologii Doświadczalnej i Klinicznej, al. Powstańców Wlkp. 72, 70-111 Szczecin \\ 2 Przychodnia Stomatologiczna „Mardent", ul. Prosta 1, 72-510 Wolin \\ ${ }^{3}$ Gabinet fizjoterapii i terapii manualnej „Animusz”, ul. Jerzego Bajana 9/49, 01-904 Warszawa \\ ${ }^{4}$ Pomorski Uniwersytet Medyczny w Szczecinie, Zakład Gerostomatologii, al. Powstańców Wlkp. 72, 70-111 Szczecin \\ $\triangle$ rpsobolewski@wp.pl
}

\section{ABSTRACT}

Aberrations of the lumbar lordosis constitute a serious health condition in every age. The pain associated with this status influences functional capability, causing low quality of life.
Lumbar pain is associated with different malfunctions. Treatment is complex and depends on the type of dysfunction and its progression.

Keywords: lumbosacral region; lumbar lordosis; hypolordosis; hyperlordosis; scoliosis.

\section{ABSTRAKT}

Zmiany w obrębie lordozy lędźwiowej stanowią bardzo poważny problem zdrowotny w każdym przedziale wiekowym. Dolegliwości bólowe towarzyszące tym zmianom wpływają na upośledzenie sprawności funkcjonalnej, a co za tym idzie - na obniżenie jakości życia.
Bóle kręgosłupa i otaczających struktur związane są z rodzajem patomechanizmu. Leczenie zależy od rodzaju patologii oraz jej zaawansowania i zwykle jest procesem złożonym.

Słowa kluczowe: odcinek lędźwiowo-krzyżowy; lordoza lędźwiowa; hipolordoza; hiperlordoza; skolioza.

\section{WSTĘP}

Zaburzenia w prawidłowej postawie ciała dotyczą najczęściej zmniejszenia bądź zwiększenia lordozy, zarówno w odcinku lędźwiowym, jak i szyjnym. Związane jest to ze zmianami w napięciu mięśni przykręgosłupowych, z dyskopatią, zwyrodnieniami i chorobami neurologicznymi, a także z nieprawidłową budową kręgów lędźwiowych.

Odcinek lędźwiowy utworzony jest z 5 masywnych kręgów L1-L5. Każdy z nich zbudowany jest z trzonu o kształcie nerkowatym od strony brzusznej i łuku kręgowego od strony grzbietowej oraz 7 wyrostków. Tworzą one otwór kręgowy dla rdzenia kręgowego. Kanał lędźwiowy ma kształt trójkątny, a jego światło w przekroju strzałkowym powinno wynosić ok. $13 \mathrm{~mm}[1]$.

Pomimo znacznej wielkości trzonów kręgów w odcinku lędźwiowym oraz dużej powierzchni i wysokości krążków międzykręgowych (dysków) ruchomość kręgosłupa jest znaczna za sprawą sprężystości krążków [2].

Wygięcie lordotyczne w tym odcinku kształtuje się podczas dzieciństwa. Norma lordozy lędźwiowej wg Gutmana wynosi $28,0-46,0^{\circ}$. Wielkość i wykształcenie lordozy zależy od takich czynników, jak: wiek, typ somatyczny, ustawienie miednicy, napięcie i długość mięśni stabilizujących stawy biodrowe.

Wygięcie to wraz z dyskami pełni funkcję amortyzacyjną. Na przekroju strzałkowym klinowate dyski swoją szerszą stroną skierowane są ku przodowi, co warunkuje wygięcie. Do krzywizny kręgosłupa dostosowuje się kanał kręgowy.

Zaburzenia prawidłowej postawy ciała są bardzo charakterystyczne i zależą od typu patologii lordozy lędźwiowej. Diagnoza nieprawidłowego wygięcia lordotycznego nie jest dużym wyzwaniem. Doświadczony terapeuta, obserwując postawę ciała pacjenta, jest w stanie bez trudu określić rodzaj zaburzenia. Wywiad z pacjentem jest potwierdzeniem wstępnej obserwacji i źródłem informacji o przyczynie zmian patologicznych. Pacjent z reguły kierowany jest na najbardziej popularne badanie obrazowe, jakim jest RTG, w celu określenia zaawansowania zmian kostnych oraz ich pochodzenia. Sposób leczenia będzie zależał od wieku pacjenta, przyczyny wystąpienia oraz skali zmian wywołanych przez chorobę.

Podstawowym krokiem w ramach leczenia zaburzeń lordozy jest kinezyterapia, która ma na celu całkowitą zmianę wszystkich nieprawidłowych nawyków związanych z postawą ciała. Można tego dokonać poprzez przywrócenie prawidłowych wzorców ruchowych, stosując m.in. proprioceptywne nerwowo-mięśniowe torowanie ruchu (proprioceptive neuromuscular facilitation). Pozytywny efekt przynoszą też ćwiczenia stabilizujące odcinek lędźwiowy kręgosłupa czy pilates. Przy prowadzeniu osoby ze skoliozą należy wziąć pod uwagę wiek, wielkość wygięcia i jego składowe, a także jego typ i rodzaj. 
W tym typie zaburzeń młodsi pacjenci z kątem $>60^{\circ}$ (III i IV stopień wielkości łuku wg Cobba) kierowani są na zabieg operacyjny.

\section{ZMIANY KRZYWIZNY LĘDŹWIOWEJ}

W procesie pionizacji człowieka zaczęły następować istotne zmiany anatomiczne, które przede wszystkim dotyczyły stóp i miednicy. Na końcu procesu ewolucyjnego znalazły się krzywizny kręgosłupa, które kształtowały się bardzo wolno - proces ewolucji liczony jest w milionach lat [3].

Fizjologiczne wygięcie w odcinku lędźwiowym, łukiem skierowane w stronę brzuszną, nosi nazwę lordozy lędźwiowej i jest charakterystyczne tylko dla człowieka. Krzywizna ta kształtuje się podczas 1.-2. r.ż., kiedy dziecko przyjmuje postawę pionową. Wiele czynników związanych z zaburzeniami w obrębie układu kostno-szkieletowego, mięśniowego i nerwowego może w konsekwencji doprowadzić do dysfunkcji tego naturalnego biologicznego wygięcia. Do najczęstszych patologii tej okolicy można zaliczyć: zwiększenie krzywizny (hiperlordoza lędźwiowa), zmniejszenie bądź wypłaszczenie (hipolordoza albo dyslordoza lędźwiowa) i odchylenie wygięcia od linii pośrodkowej ciała w płaszczyźnie czołowej (skolioza). Wymienione dysfunkcje można podzielić na wrodzone (pierwotne) i nabyte (wtórne). Zmiany pierwotne najczęściej związane są ze zniekształceniem części kostnych, tj. kręgów i kości, zaś tkanki miękkie (tj. mięśnie, powięzi, rdzeń kręgowy, więzadła, naczynia krwionośne, nerwy) dostosowują się do patologicznej zmiany i również w nich dochodzi do zaburzenia homeostazy. Zmiany wtórne w dużej mierze są wynikiem nierównowagi mięśniowej między agonistami i antagonistami, które przyczepiając się do struktur kostnych i pociągając je, doprowadzają do zaburzeń w obrębie lordozy lędźwiowej [4].

\section{HIPERLORDOZA}

Zwiększenie łuku lordotycznego nazywane jest hiperlordozą. Patologia ta wraz ze skoliozą należy do najczęściej spotykanych dysfunkcji odcinka lędźwiowego. Może być przyczyną ostrych dolegliwości bólowych. Charakterystyczna sylwetka osób z hiperlordozą lędźwiową związana jest z nadmiernym napięciem mięśni i ich skróceniem, co w konsekwencji prowadzi do wyhamowania działania antagonistów. Zwiększonemu tonusowi ulegają takie mięśnie, jak: prostownik grzbietu w odcinku lędźwiowym, czworoboczny lędźwi, najszerszy grzbietu (część dolna), biodrowo-lędźwiowy oraz prosty uda. Ten ostatni, przyczepiając się do kolców talerzy biodrowych, powoduje obrót miednicy ku przodowi zwany przodopochyleniem. Przeciwna grupa mięśniowa otrzymuje impuls z ośrodkowego układu nerwowego: „wyhamuj czynność”. W mięśniach tych wówczas dochodzi do ich osłabienia i zmniejszenia masy. W hiperlordozie lędźwiowej mięśnie, o których mowa, to: mięśnie brzucha, mięśnie pośladkowe oraz kulszowo-goleniowe. Opisane zaburzenia noszą nazwę nierównowagi mięśniowej.
Hiperlordoza lędźwiowa może być spowodowana złymi nawykami ruchowymi, nadmierną masą ciała, a także ograniczeniem aktywności fizycznej - co w konsekwencji powoduje zaburzenia statyki w obrębie odcinka lędźwiowego i miednicy [5]. Do takiej samej sytuacji może doprowadzić chodzenie na wysokich obcasach, a także okres ciąży, kiedy wzmaga się produkcja estrogenu rozluźniającego aparat więzadłowy [6]. Wrodzoną (pierwotną) hiperlordozę lędźwiową może wywoływać: nieprawidłowe ustawienie kości krzyżowej, przerwanie łuku kręgu bez jego przemieszczenia, spondylolisteza, lumbalizacja kręgu S1 i sakralizacja kręgu L5. Przyczynami wtórnej (nabytej) hiperlordozy może być: dystonia mięśniowa, osłabienie i rozciągnięcie mięśni, krzywica, zmiany pourazowe, hiperlordoza statyczna Huca (tzw. plecy wklęsłe), zaburzenia emocjonalne, choroby neurologiczne związane z porażeniem mięśni [7, 8, 9].

Warto zwrócić uwagę na inny interesujący podział dokonany przez Rakowskiego, który wyróżnia dwa typy hiperlordozy lędźwiowej: wiotką i sztywną. Jego zdaniem hiperlordoza lędźwiowa wiotka występuje przede wszystkim u osób otyłych, unikających wysiłku fizycznego i prowadzących siedzący tryb życia. Postawa taka skutkuje osłabieniem mięśni brzucha, w wyniku czego dochodzi do odchylania tułowia do tyłu w celu utrzymania równowagi. Problem hiperlordozy lędźwiowej sztywnej najczęściej dotyczy osób ciężko pracujących fizycznie, u których dźwiganie i podnoszenie ciężarów odbywa się bez udziału stabilizatorów odcinka lędźwiowego [10].

W niniejszej pracy celowo zwrócono uwagę na zagadnienie hiperlordozy, gdyż w patologii tej ból pochodzący z zaburzonej funkcji mięśni i więzadeł jest często mylony z bólami innego pochodzenia, np. z podrażnionych więzadeł ból promieniować może do kończyn dolnych i często mylony jest z rwą kulszową i lumbago. Więzadło biodrowo-lędźwiowe generuje ból do okolic wyrostka kolczystego kręgu L5 oraz grzebienia biodrowego po stronie podrażnienia. Czasem ból promieniuje do pachwiny. W wyniku zwiększenia krzywizny wyrostki kolczyste kręgów lędźwiowych zbliżają się do siebie, co powoduje zmniejszenie przestrzeni międzywyrostkowej, a w ślad za tym ucisk i podrażnienie więzadeł międzykolcowych i nadkolcowych. Rakowski opisał mechanizm podrażnienia więzadeł biodrowo-krzyżowych w hiperlordozie lędźwiowej, gdzie doszło do skrócenia prostowników grzbietu odcinka lędźwiowego, zaś mięśnie biodrowo-lędźwiowe i mięśnie proste uda zachowały normalną długość. Wówczas dochodzi do ustawienia kości krzyżowej w nutacji, co powoduje podrażnienie tych więzadeł [10]. W wyniku zwiększenia lordotycznego zaburzeniom ulegają również stawy międzykręgowe (stawy międzywyrostkowe), w których dochodzi do ich podwichnięć objawiających się bólem. Nadmierny tonus w skróconych mięśniach przyczynia się do powstania punktów spustowych, z których ból może promieniować do odległych struktur położonych daleko od ich źródła. Topografia bólu zależy od umiejscowienia punktu spustowego. Hiperlordoza wtórna (inaczej funkcyjna) jest w najnowszej literaturze określana jako zespół skrzyżowania dolnego. W patologii tej nie występują zaburzenia struktury i funkcji, w związku z tym w obrazie RTG nie obserwuje się zmian strukturalnych. Widoczna jest jedynie zwiększona 
lordoza lędźwiowa. Z upływem czasu nieleczony zespół skrzyżowania przeistacza się w zespół funkcjonalny (ograniczający niektóre funkcje ruchowe kręgosłupa), a następnie problem ten obejmuje struktury kostno-stawowe.

\section{HIPOLORDOZA LĘDŹWIOWA}

Dysfunkcją przeciwstawną do hiperlordozy jest hipolordoza charakteryzująca się zmniejszeniem naturalnego wygięcia lordotycznego w płaszczyźnie strzałkowej. Dysfunkcja ta występuje dużo rzadziej niż poprzednia. W projekcji bocznej sylwetka chorego cechuje się ustawieniem miednicy w tyłopochyleniu, gdzie pośladki są „schowane”, a kość ogonowa „podwinięta”, czego konsekwencją jest nierównowaga mięśniowa tej okolicy [11, 12]. Na skutek zmniejszenia wygięcia lub jego wypłaszczenia dochodzi do rozciągnięcia mięśni - prostownika grzbietu odcinka lędźwiowego oraz równoległobocznego lędźwi [13, 14].

Norma długości zachowana jest w mięśniu biodrowo-lędźwiowym i prostym uda. Skróceniu zaś ulegają prostowniki stawu biodrowego. Mięsień prosty brzucha może ulec nieznacznemu skróceniu bądź zachować swoją długość, rzadko kiedy jednak ulega osłabieniu. W dysfunkcji tej dość często dochodzi do wygarbienia łuku ku tyłowi, co przypomina kifozę tego odcinka. W tej sytuacji zmniejszają się przestrzenie w części brzusznej trzonów kręgów lędźwiowych, natomiast zwiększenie następuje od strony kanału. Sprzyja to naderwaniom włókien wchodzących w skład pierścienia włóknistego, a co za tym idzie - wysuwaniu się substancji galaretowatej (jądra miażdżystego). Zaburzeniom ulegają również więzadła stawu krzyżowo-biodrowego (bezpośrednie i pośrednie) oraz więzadła nadkolcowe i międzykolcowe. Znacznemu skróceniu ulega więzadło krzyżowo-guzowe, z którego ból promieniuje do całej kończyny dolnej wraz z palcami (podobna topografia występuje przy uciśnięciu korzenia S1), natomiast rozciągnięte zostają więzadła: międzykolcowe, nadkolcowe i biodrowo-lędźwiowe. Sytuacja ta jest odwrotna niż w hiperlordozie, ale zarówno rozciągnięcie, jak i skrócenie tych więzadeł generuje ból o tym samym charakterze i topografii. Punkty spustowe u pacjentów z dyslordozą lędźwiową najczęściej usytuowane są w mięśniach pośladkowych [15].

\section{SKOLIOZA}

Innym rodzajem zaburzeń w obrębie lordozy lędźwiowej jest skolioza, dawniej nazywana skrzywieniem bocznym. Obecnie wiadomo, że w skrzywieniu tym dochodzi do zaburzeń zarówno w płaszczyźnie czołowej i strzałkowej, jak i horyzontalnej. Jest to zatem skrzywienie trójpłaszczyznowe [16, 17, 18]. Istnieje wiele form skoliozy uzależnionych od stosunku zmian w poszczególnych płaszczyznach. Niekiedy zaburzenie w płaszczyźnie czołowej jest dużo większe niż w pozostałych, wówczas łuk skoliozy będzie bardziej widoczny. Bywają sytuacje, gdy dochodzi do znacznej rotacji kręgów; stosunek zaburzeń jest wtedy w płaszczyźnie horyzontalnej, co objawia się garbem [19].
Jest wiele podziałów tego schorzenia. Jeden z nich wyróżnia skoliozę pierwotną i w tórną, inny zależny jest od stopnia skrzywienia, a jeszcze inny nawiązuje do jej umiejscowienia. Ze względu na częstotliwość występowania na szczególną uwagę zasługują cztery rodzaje skoliozy: wrodzona, nerwowo-mięśniowa, zwyrodnieniowa i idiopatyczna [16, 20].

Skolioza wrodzona (niemowlęca) rozpoznawana jest przed ukończeniem przez dziecko 3. r.ż., a jej najczęstszą przyczyną jest deformacja trzonu kręgu, która objawia się tym, że po jednej stronie jego wysokość jest większa niż po stronie przeciwnej. Ma to związek z nierównomiernym wykształceniem się jednej połowy kręgu. Skolioza nerwowo-mięśniowa najczęściej związana jest z dystrofią mięśniową i mózgowym porażeniem dziecięcym, czyli z uszkodzeniem układu nerwowego, co doprowadza do nierównowagi mięśniowej, a w konsekwencji do skrzywienia. Skolioza zwyrodnieniowa dotyczy osób starszych, po 60. r.ż., u których zaburzeniom ulegają zarówno krążki międzykręgowe (dehydratacja), jak i stawy międzykręgowe, co w konsekwencji przyczynia się do niestabilności kręgosłupa. Skolioza idiopatyczna występuje u 2-3\% populacji. Jej etiologia nie jest znana [21]. Przypuszcza się jedynie, że może mieć związek z predyspozycją genetyczną, skokiem wzrostowym lub zmianami w ośrodkowego układzie nerwowym. W skoliozie po stronie wypukłej tkanka miękka (mięśnie, więzadła, torebki stawowe, naczynia krwionośne, nerwy) ulega rozciągnięciu, zaś po stronie wklęsłości skraca się, doprowadzając do powstania punktów spustowych. Podsumowując, można stwierdzić, że zaburzenie struktur okołostawowych zależne jest od wielkości i charakteru skoliozy [22].

\section{PODSUMOWANIE}

Odcinek lędźwiowy wchodzący w skład kręgosłupa jest fragmentem łańcucha biokinematycznego, dlatego też jakiekolwiek zaburzenie tego rejonu ma wpływ na pozostałe ogniwa. Dla przykładu skolioza pierwotna w odcinku lędźwiowym doprowadza do powstania skoliozy wyrównującej w odcinku piersiowym. Innym przykładem jest hiperkifoza piersiowa będąca wynikiem hiperlordozy lędźwiowej. W innych przypadkach dochodzi do wypłaszczenia kifozy piersiowej w hiperlordozie lędźwiowej [19, 23].

Istnieje wiele mechanizmów kompensacyjnych na pozostałych piętrach kręgosłupa.

\section{PIŚMIENNICTWO}

1. Sierota A, Wrzosek Z. Analiza przyczyn rwy kulszowej w badaniach własnych. Baln Pol 2008;3:213-20.

2. Maciejewski R, Torres K. Anatomia czynnościowa. Lublin: Wyd. Czelej; 2007. p. 104-6.

3. Ucieklak J, Sawicki G. Bóle kręgosłupa jako problem cywilizacyjny. Fam Med Primary Care Rev 2006;3:1133-35.

4. Nachemson A. The load on lumbar disc in different positions of the body. Clin Orthop Relat Res 1966;45:107-22.

5. Dziak A, Tayara S. Bóle krzyża. Kraków: Kasper; 1997 
6. Kiwerski J. Rehabilitacja medyczna. Warszawa: PZWL; 2005.

7. Chaitow L, DeLany J. Clinical application of neuromuscular techniques. Practical case study exercises. Livingstone: Churchill; 2005.

8. Stodolny J. Choroba przeciążeniowa kręgosłupa. Epidemia naszych czasów. Kielce: ZL Natura; 1996.

9. Danneels LA, Vanderstraeten G, Cambier D, Witvrouw E, Bourgois J, Dankaerts W, et al. Effect of three different training modalities on the cross sectional area of the lumbar multifidus muscle in patient with chronic low back pain. Br J Sports Med 2001;35(3):186-91. doi: 10.1136/bjsm.35.3.186

10. Rakowski A. Kręgosłup w stresie: jak pokonać ból i jego przyczyny. Gdańsk: GWP; 2001.p. 59.

11. Czapka B, Goguł P, Maksim A. Wpływ mobilizacji odcinka lędźwiowego na zachowanie się krzy wizn kręgosłupa. Uniwersy tet Medyczny w Lublinie, Sympozjum Naukowe, Collegium Maius, Lublin, 8.05.2014.

12. Janikowska K, Chomiuk K, Majewska D. Ocena jakości życia pacjentów z zespołem bólowym dolnego odcinka kręgosłupa. Uniwersytet Medyczny w Lublinie, Sympozjum Naukowe, Collegium Maius, Lublin, 8.05.2014.

13. Kluszczyński M, Czernicki J, Kubacki J. Ocena plurimetryczna zmian krzywizn kręgosłupa w płaszczyźnie strzałkowej w 10-letniej obserwacji u dzieci i młodzieży. Adv Rehab 2013;27(2):5-12. doi: https://doi. org/10.2478/rehab-2014-0008.

14. Wojna D, Anwajler J, Barczyk K. Postawa ciała w płaszczyźnie strzałkowej dzieci w starszym wieku przedszkolnym. Fizjoterapia 2006;14(4):29-37.
15. Simons DG, Travell J, Simons LS. Myofascial pain and dysfunction. The trigger point manual. Baltimore: Williams \& Wilkins; 1999.

16. Głowacki M, Kotwicki T, Pucher A. Skrzywienie kręgosłupa. In: Marciniak W, Szulc A, editors. Wiktora Degi ortopedia i rehabilitacja. Warszawa: PZWL; 2003. p. 68-111.

17. Nowakowski A, Napiontek M, Rzymski K. Torsja i rotacja kręgu szczytowego oraz zniekształcenie klatki piersiowej w idiopatycznych skoliozach piersiowych badanych w tomografie komputerowym. Chir Narz Ruchu Ortop Pol 1991;56:6-7.

18. Żuk T, Dziak A. Propedeutyka ortopedii. Warszawa: PZWL; 1977.

19. Nowak R, Tokarski A, Dec J, Wójcik K, Wojciechowski P. Patomechanika deformacji kręgosłupa i klatki piersiowej w skoliozie idiopatycznej. Chir Narz Ruchu Ortop Pol 1997;62:211-7.

20. Erkula G, Sponseller PD, Kiter AE. Rib deformity in scoliosis. Eur Spine J 2003;12:281-7. doi: 10.1007/s00586-002-0523-6.

21. Kotwicki T, Szulc A, Dobosiewicz K, Rąpała K. Patomechanizm progresji skolioz idiopatycznych - znaczenie fizjologicznej kifozy piersiowej. Ortop Traumatol Rehabil 2002;4(6):758-65.

22. Kotwicki T, Chêneau J. Biomechanical action of a corrective brace on thoracic idiopathic scoliosis: Chêneau 2000 orthosis. Disabil Rehabil Assist Technol 2008;3(3):1-8. doi: 10.1080/17483100801905744.

23. Kowalski IM. Wady postawy i skrzywienia kręgosłupa. In: Latkowski JB, Lukas W, editors. Medycyna rodzinna. Warszawa: PZWL; 2009. 